\title{
LOVING AND HATING IN ENGLISH AND PORTUGUESE: A CORPUS-BASED CONTRASTIVE STUDY
}

\author{
SIGNE OKSEFJELL EBELING
}

\section{RESUMO}

Este trabalho, inspirado pelo artigo de Stig Johansson sobre "Loving and hating" em inglês e norueguês (Johansson 1998), aplica métodos semelhantes ao par português-inglês.

Usando traduções nos dois sentidos no ENPC, Johansson comparou os verbos love e hate em inglês com as suas contrapartidas norueguesas elske e hate, concluindo que há diferenças entre o uso destes verbos, embora sejam altamente correlacionados. Os verbos noruegueses exprimem em geral um sentimento forte, enquanto os verbos ingleses também são usados num sentido mais fraco, mais frequente em combinação com objetos não humanos ou completivas.

Com base num subconjunto do COMPARA, o presente estudo investiga o que se pode concluir da comparação entre love e hate ingleses e os verbos amar e odiar em português. Os resultados são menos claros: se, por um lado, os verbos portugueses parecem alinhar com os noruegueses no sentido de terem uma área de aplicação mais restrita do que os ingleses, por outro lado o verbo odiar é muito mais usado com objetos não humanos do que o verbo norueguês hate. Esta e outras observações contrastivas sugerem que é mais fácil em português do que em norueguês atribuir a objetos não humanos "sentimentos fortes", enquanto que em inglês os verbos são usados com um sentido mais fraco.

\section{[1] INTRODUCTION}

The semantics and syntax of the lexicon of Emotion have provided linguists with food for thought for some time.

$$
\text { (Maia 1994/1996, Preface) }
$$

This paper focuses on the English verbs love and hate and their Portuguese counterparts amar and odiar. The choice of topic is inspired by previous crosslinguistic studies of the language of emotion (Maia 1994/1996; Johansson 1998; 
Maia \& Santos 2012), and most notably by Johansson's (1998) article entitled "Loving and hating in English and Norwegian". ${ }^{1}$

Drawing on bidirectional translation data from the fiction part of the EnglishNorwegian Parallel Corpus ${ }^{2}$ (ENPC), Johansson compares the English verbs love and hate and their Norwegian correspondences elske and hate. He concludes that there are cross-linguistic differences in the use of these closely related verbs. The Norwegian verbs typically "express a strong feeling", and are therefore more prone to appear with a personal object, while the English verbs "are also used in a weakened sense" which is "most likely to appear where the verbs combine with non-personal objects, particularly complement clauses" (Johansson 1998, pg. 101). Examples (1) and (2) illustrate the use of English love in its strong sense (with a personal object) and weakened sense (with a non-personal, clausal object), respectively. Norwegian translations from the ENPC are also provided, where the direct counterpart elsket is used as a translation of loved in (1), and veldig gjerne 'very gladly' of an arguably semantically weaker love in (2).

(1) I loved Natalie.

(ENPC/FW1)

Jeg elsket Natalie.

(ENPC/FW1T)

(2) I'd love to try it.

(ENPC/RD1)

Den vil jeg veldig gjerne prøve.

(ENPC/RD1T)

Lit.: That will I very gladly try

The current study seeks to establish to what extent conclusions similar to those drawn for English vs. Norwegian also apply to the language-pair English-Portuguese. In other words, what is typically loved and hated in English and Portuguese? Are the Portuguese verbs closer to the English or the Norwegian verbs in terms of meaning and use? Answers to these questions will primarily be sought in material culled from a subset of the COMPARA corpus (see e.g. FrankenbergGarcia \& Santos (2003)).

Providing essential background information, both in terms of object of study and method, Section [2] outlines Johansson's study in more detail. The corpus used in the present investigation is presented in Section [3], while Section [4] contains the contrastive analysis proper. Some concluding remarks are offered in Section [5].

[1] A revised version of the article is published as Chapter 5 in (Johansson 2007).

[2] Cf. Johansson \& Hofland (1994), Oksefjell (1999). 
[2] BACKGROUND

Johansson's interest in the verbs under study was sparked as he noticed some odd uses of Norwegian hate appearing in the newspaper. The examples that triggered the original study are repeated here as (3) and (4), and were found to be direct translations from English.

(3) Jeg hater å bringe sladderen videre.

(Translation of 'I hate to pass gossip on')

(4) Jeg hater å bruke mine egne skader for å skape troverdighet.

(Translation of 'I hate to use my own injuries to establish credibility')

Johansson's immediate reaction was that these were instances of anglicisms, "inspired by the English source texts" (1998, pg. 93), and therefore not considered idiomatic Norwegian. These observations made him want to take a closer look into the relationship between the English and Norwegian cognate verbs hate/hate. He also included in his investigation their more loveable opposites: love and elske.

In the material from the ENPC, he noticed that, in the original texts, the English verbs were more than three times as frequent as the Norwegian verbs. In the translated texts, however, the frequencies "move in the direction of the frequencies found for the corresponding verbs in original texts in the source language" (ibid., pg. 94), as shown in Table 1.

\begin{tabular}{lcc}
\hline & Original texts & Translations \\
\hline N hate & 23 & 34 \\
N elske & 36 & 90 \\
E hate & 67 & 25 \\
E love & 100 & 62 \\
\hline
\end{tabular}

TABLE 1: Frequency figures for the four verbs in original and translated texts in the ENPC.

The tendency for linguistic patterns to behave differently in original vs. translated texts may be caused by source language influence on the target language. This phenomenon has been termed translationese (see e.g. Gellerstam (1986)), and Johansson suggests that "it is highly likely that the occurrences of Norwegian hate in examples (3) and (4) above are examples of translationese" (Johansson 1998, pgs. 94-94).

Johansson moves on to discuss the overall translation patterns in the ENPC material, and finds that Norwegian hate and elske are almost invariably translated by their English counterparts hate and love, while the English verbs often have other renditions in Norwegian than hate and elske. This suggests that the Norwegian verbs have a more restricted area of use than their English cousins. 
Moreover, the complementation patterns of the verbs, i.e. the type of object they typically combine with, show further cross-linguistic differences, as illustrated in Table 2.

\begin{tabular}{|c|c|c|c|c|}
\hline & \multicolumn{2}{|c|}{ Original texts } & \multicolumn{2}{|c|}{ Translations } \\
\hline & Personal Obj. & Non-personal Obj. & Personal Obj. & Non-personal Obj. \\
\hline $\mathrm{N}$ hate & $65 \%$ & $35 \%$ & $35 \%$ & $65 \%$ \\
\hline $\mathrm{N}$ elske & $61 \%$ & $39 \%$ & $35 \%$ & $64 \%$ \\
\hline E hate & $27 \%$ & $73 \%$ & $56 \%$ & $44 \%$ \\
\hline E love & $46 \%$ & $54 \%$ & $65 \%$ & $35 \%$ \\
\hline
\end{tabular}

TABLE 2: Type of object following the verbs in original and translated texts (in percent) in the ENPC (ibid., pg. 95).

Focusing on the original texts in the two languages, we can note that the Norwegian verbs prefer a personal object, while the English verbs prefer nonpersonal objects. Johansson comments on the translations and says that " $t]$ he translated texts again show a frequency pattern which reflects the source texts" (ibid.), thus a greater proportion of the Norwegian translations than expected used elske/hate with the weakened sense and the complementation patterns typical of the English love/hate.

Johansson's study continues with an analysis and a discussion of the Norwegian translation correspondences and he concludes that the differences between the English and Norwegian verbs "come out very clearly both in the overall frequency of the verbs in original texts and in their translation patterns" (ibid., pg. 101). He also notes that, the distribution differences between original and translated texts notwithstanding, the translators generally seem to be aware of these differences, as attested by the rich inventory of translation correspondences. Nevertheless, the influence from English on the Norwegian language is pervasive and may lead to the use of Norwegian hate/elske in a weakened sense. In fact, Johansson suggests that the Norwegian verbs may be undergoing a semantic change. This "new" weakened use of the two Norwegian verbs has indeed been attested in two follow-up studies based on more recent corpus material (Hasselgård 2011; Ebeling 2014).

The present study adds another language to the equation, and will follow Johansson's steps in the analysis with the aim of gaining insight "which goes beyond the establishment of standard counterparts" (Johansson 1998, pg. 103), viz. love/amar and hate/odiar. ${ }^{3}$

[3] In an article entitled "Loving and hating the movies in English, German and Spanish", Taboada et al. (2014) study evaluative language in the genre movie reviews. Their focus is not specifically on the verbs love and hate, but they mention, referring Johansson (1998), that 'love' and 'hate' and their equivalents in German and Spanish are actually quite infrequent in our corpus, because they express Affect, which [...] is not very frequent in our corpus, in contrast to Appreciation" (Taboada et al. 2014, pg. 131). 
At this point, reference should be made to Maia's (1994/1996) extensive work on emotions in English and Portuguese. Particularly relevant in the current context are her observations on the verb patterns found with verbs of emotion: "Complementation by non-finite clauses is fairly common with certain SFoc [SENSER focusing] Emotion verbs in English", including love and hate. She also notes that this structure is more common with English verbs of emotion than with Portuguese verbs of emotion. Interestingly, as a Portuguese rendering of English I love playing football, she opts for Gosto de jogar futebol rather than?Amo jogar futebol. It should be mentioned that Maia's scope is broader and her focus slightly different from the current one - being more concerned with the cognitive aspects of emotion, and how human beings conceptualise emotion through language. Thus, the current study will mainly refer to Johansson's (1998) analysis.

\section{[3] MATERIAL}

As mentioned in the Introduction, the main source of data used in this investigation is a subset of the COMPARA corpus. COMPARA contains original texts in English and Portuguese with their translations into the other language, and is thus similar to the ENPC in being a bidirectional translation corpus. Worth mentioning in this context is that Portuguese was one of the languages that was added in the multilingual extension of the ENPC, later known as the Oslo Multilingual Corpus (OMC) (see Oksefjell (1999); Johansson (2007)). As the Portuguese part of the OMC is unidirectional, i.e. it contains Portuguese translations of English texts but not vice versa, COMPARA was a more natural choice of corpus for this study. However, some of the texts in the (English-Portuguese part of the) OMC and COMPARA overlap.

In order to make this study as comparable as possible to Johansson's, a selection of texts available in COMPARA was made, according to the following criteria:

- Original texts mainly from the 1980 s and $1990 s^{4}$

- A maximum of two texts per author ${ }^{5}$

The version of COMPARA used here thus contains 20 original text extracts in Portuguese, amounting to approx. 370,000 words and 14 original text extracts in English, amounting to approx. 360,000 words, in addition to a similar amount of text of their respective translations (see the Appendix for a full list of texts included). ${ }^{6}$ The fact that different varieties of both Portuguese and English are

\footnotetext{
[4] One Portuguese text (PPJS1) was published in the late 1970s (but so were some of the Norwegian texts in the ENPC).

[5] To ensure as balanced a corpus as possible in terms of size, three texts by one Brazilian author were included (PBPC).

[6] For comparison, the ENPC contains roughly 400,000 words of original text in each language.
} 
included among the texts has not been given special attention in the current investigation. This is mainly due to the limited material at hand, both in terms of authors represented and amount of text from each variety. Nevertheless, this is certainly a topic worthy of future study, as regional variation is likely to occur also in the use of love and hate expressions.

Before we move on to the actual material extracted from the corpus, a comment on the choice of Portuguese verbs to study is in order. Amar and odiar are intuitively the closest counterparts of the English verbs, although there may be other Portuguese verbs that come to mind. However, the close relationship between love/amar and hate/odiar is confirmed in a number of bilingual dictionaries, where invariably these are the verbs that are given first as each other's translations. ${ }^{7}$ And as we shall see below, the bidirectional data from COMPARA confirms their strong intertranslatability. Other verbs that are mentioned in the dictionaries include adorar and gostar (de) for love and detestar for hate. Interesting in the current context is a note on the use of odiar in The Routledge Portuguese Bilingual Dictionary:

Odiar is not as casually used as is 'hate' in English. Ex: 'I hate cabbage'. In Portuguese you would say 'detesto couves' or 'não gosto de couves'.

Searches for all forms of the verbs love, hate, amar and odiar were made in both the original and translated texts of COMPARA, ${ }^{8}$ and the overall frequencies are presented in Table 3. False hits, such as noun uses of love and ama 'nanny' / 'wetnurse', are excluded in this overview.

\begin{tabular}{lcc} 
& \multicolumn{2}{c}{ COMPARA } \\
\hline & Original texts & Translations \\
& $(\mathrm{E}: 359,281 / \mathrm{P}: 369,203)$ & (E: $412,704 / \mathrm{P}: 350,607)$ \\
\hline P odiar & $39(10.6$ per 100,000 words $)$ & $16(4.6$ per 100,000 words $)$ \\
P amar & $54(14.6$ per 100,000 words $)$ & $30(8.6$ per 100,000 words $)$ \\
E hate & $37(10.3$ per 100,000 words $)$ & $49(11.9$ per 100,000 words $)$ \\
E love & $84(23.4$ per 100,000 words $)$ & $96(23.2$ per 100,000 words $)$ \\
\hline
\end{tabular}

TABLE 3: Overall frequencies of the four verbs, including normalized frequencies per 100,000 words

The Portuguese verbs show the opposite trend compared to their Norwegian counterparts, i.e. they are less commonly attested in translations from English than in original Portuguese texts. Another observation worth making is that the English verbs are fairly stable across original and translated texts. In Johansson's

[7] See e.g. Collins Portuguese Dictionary and The Routledge Portuguese Bilingual Dictionary.

[8] Henceforth, COMPARA refers to the subset used here. 
data, however, the English translations seemed to be drawn towards the Norwegian source texts in being less frequently used.

As English love is more frequent than amar overall (both in original texts and translations), it seems fair to suggest that love has a wider area of use than amar. Odiar and hate, on the other hand, occur with a similar frequency in original texts, while the use of odiar drops in translations. In contrast to the English-Norwegian data, the difference in distribution of odiar and amar in original vs. translated text does not seem to be a case of translationese, as their distribution is not pulled towards the use in the source language English. In fact, the reason for this discrepancy is hard to pin down, but, with regard to the former verb, could the notion of odiar not being used as "casually" as hate play a role in the minds of the translators?

\section{[4] CONTRASTIVE ANALYSIS}

Following Johansson's steps in the analysis, we will first take a look at the overall translation patterns before moving on to the actual translation correspondences.

\section{[4.1] Overall Translation Patterns}

The intertranslatability of the verb-pairs is shown in Table 4, where the number of times the verbs-pairs are not translated into each other is recorded (Johansson 1998, pg. 95).

\begin{tabular}{llll}
\hline P odiar & NOT & E hate & 0 (out of 39$)$ \\
P amar & NOT & E love & 7 (out of 54) \\
& & & \\
E hate & NOT & P odiar & 21 (out of 37$) \approx 57 \%$ \\
E love & NOT & P amar & 54 (out of 84$) \approx 64 \%$ \\
\hline
\end{tabular}

TABLE 4: The intertranslatability between odiar:hate and amar:love.

Table 4 shows remarkably similar tendencies regarding the relationship between the verbs in English-Norwegian and English-Portuguese. As in the case of the Norwegian verbs, Portuguese odiar and amar are almost invariably translated into English hate and love, respectively. Of the seven instances that do not have a form of the verb love in the translation, five have the noun love instead, as in:

(5) Não amava o próximo...

(PBRF1)

He had no love for his fellow man...

In one case being unloved has been used as a translation of não ser amado, while the last example is a direct quotation from the Bible and has betrothed a wife as a translation of ama uma mulher. 
In the other direction of translation, however, the Portuguese verbs are only used as translations of hate and love in roughly $60 \%$ of the cases, i.e. other Portuguese translations correspondences are used in approx. $40 \%$ of the occurrences. There is thus a translation bias in the use of these verbs as correspondences of each other (Altenberg 1999, pg. 255ff). Transferring Johansson's interpretation of a similar translation bias in the English-Norwegian material, we can tentatively conclude that the English verbs have a wider area of use than odiar and amar. (The overall frequencies shown in Table 3 already suggested this in the case of love.)

As seen in Table 2, Johansson also found a clear difference between English and Norwegian in the use of type of object following the verbs. A comparable overview for the COMPARA data is given in Table 5.

\begin{tabular}{lrrrrr} 
& \multicolumn{2}{c}{ Original texts } & & \multicolumn{2}{c}{ Translations } \\
\cline { 2 - 3 } \cline { 5 - 6 } & $\begin{array}{c}\text { Personal } \\
\text { objects }\end{array}$ & $\begin{array}{c}\text { Non-personal } \\
\text { objects }\end{array}$ & & $\begin{array}{c}\text { Personal } \\
\text { objects }\end{array}$ & $\begin{array}{c}\text { Non-personal } \\
\text { objects }\end{array}$ \\
\hline P odiar & $51.0 \%$ & $49.0 \%$ & & $68.8 \%$ & $31.2 \%$ \\
P amar & $76.0 \%$ & $24.0 \%$ & & $63.3 \%$ & $36.7 \%$ \\
E hate & $37.8 \%$ & $62.2 \%$ & & $51.0 \%$ & $49.0 \%$ \\
E love & $57.1 \%$ & $42.9 \%$ & & $53.1 \%$ & $46.9 \%$ \\
\hline
\end{tabular}

TABLE 5: Type of object following the verbs in original and translated texts (in percent) in COMPARA

If we look at the distribution of the English verbs first, we can note that hate clearly favours a non-personal object in the original texts, while love prefers a personal object. While the former observation is in line with Johansson's original study, the latter is not; i.e. love was found to be slightly more common with a nonpersonal object. However, as the distribution of love showed the least discrepancy between personal vs. non-personal object in Johansson's study (see Table 2), the choice seems to be arbitrary and most likely due to subject matter of the individual texts.

In the Portuguese original texts there is a clear preference for personal objects with amar, while in the case of odiar there is a less clear-cut division of labour between complementation patterns. A typical example of amar with a personal object is shown in example (6), while examples (7) and (8) show odiar with a personal and non-personal object, respectively.

(6) Tenho duas coisas importantes para te dizer: a primeira é que eu te amo.

[PBPM2]

I have two important things to tell you: the first is that I love you.

(7) Mas não somos amigos, eu te odeio.

[PBRF1]

But we're not friends. I hate you. 
(8) Eu passara a odiar aquela ausência.

[PMMC2]

I had come to hate that absence.

As can be seen from Table 5, the verbs tend to favour personal objects also in the translations; this is true even of English hate, albeit only marginally so. This is related to the use of odiar in the source texts (also with a slight overweight of personal objects) and the fact that hate is always used as a translation of odiar in the material at hand (see Table 4 and examples (7) and (8)). It is harder to explain why the percentage of odiar with a personal object increases to the extent that it does in the translations, but again it seems to be related to the fact that the other main translation option of hate (besides odiar) - detestar 'detest' - takes care of many of the instances where hate has a non-personal object in the original texts, as exemplified in (9) where the object is realised by an infinitive clause.

(9) I hate to see it falling on to the barber-shop floor...

[EBDL1T1]

Detesto ver o cabelo a cair para o chão da barbearia...

Whether this suggests that the translators view odiar as being semantically too strong or unidiomatic in contexts such as (9) is hard to determine, though. It is also hard to determine what happens to amar and love in the translations, as both show a slight decrease in personal objects and a slight increase in non-personal objects. The reason for this may become clearer when we turn to the next step in the contrastive analysis, focusing on the actual translations correspondences of the four verbs under study.

\section{[4.2] Translation correspondences}

As we have seen (in Table 4 in particular) there is a tendency for translators to choose the standard counterpart of the verbs in the other language. The translation correspondences in the COMPARA material generally follow the same pattern as in Johansson's study, i.e. the Portuguese verbs are almost invariably translated into the English counterparts love and hate, while the English verbs show a greater variety of Portuguese translations (see Table 4). In the following we will therefore focus on translations of the English verbs only.

Translations of English hate

Complement clauses

English hate is followed by a complement clause in four out of the 37 occurrences - two-ing clauses and two to-infinitive clauses. In none of these four cases did the translators use odiar to translate hate; the most common translation is detestar 'detest' with three occurrences, cf. example (9) above. In one case, não 
gostar (de) 'not like' was used, e.g. (10). Detestar 'detest' as a translation of hate followed by an -ing clause is illustrated in (11). In all but one of the Portuguese translations an infinitival complement clause was chosen; in (11) a finite clause was added instead.

(10) I'd hate to have to worry about an anorexic bird.

[EURZ2] Não gostava nada de ter de andar preocupado com um pássaro anoréxico.

(11) Barbara had, long ago, hated being called 'Mum'...

[EBJT2] Há muito que Barbara detestava que lhe chamassem "mãe"...

Thus, where Norwegian was shown not to readily accept a "hate"-verb with clause complementation, Portuguese has detestar. However, odiar does not seem to be completely ruled out, as there were two instances of odiar + infinitive clause in the Portuguese originals. A brief comparison of instances per million words (pmw) of amar, odiar, love and hate followed by an infinitive in monolingual corpora shows the following: amar + inf.: 0.16 pmw, odiar + inf.: 0.28 pmw (based on "corpo todos juntos" through the AC/DC project; ${ }^{9}$ love + to-inf.: 11.41 pmw, hate + to-inf.: 3.99 pmw (based on the British National Corpus BNCWeb cqp edition).

Other non-personal objects

The other non-personal objects attested form a very homogeneous group, consisting of a noun phrase in all but one of the 19 instances. 14 of these have detestar in the translation, e.g. (12), while only four have odiar, e.g. (13). The one instance without a following noun phrase is a passive construction translated by odiado.

D'you hate spinach?

[EBJT1] Detestas espinafres?

(13) I especially hate banks and post offices...

[EBDL1T1] Odeio especialmente bancos e estações de correios...

A variety of non-personal nouns are represented in the material, including ties/ gravatas, the IRA/o IRA, spinach/espinafres as in (12) and banks/bancos, as in (13). Such a variety was also noted by Johansson (1998) for English and Norwegian. However, with regard to the wider area of use of English hate, Johansson recorded a number of different recurrent verb correspondences in the Norwegian translations, while it in the English-Portuguese material restricts itself to odiar and detestar, of which the former seems to have a preference for personal objects and the latter a preference for non-personal objects.

[9] http://linguateca.pt 
Personal objects

When hate is followed by a personal object, the translators have chosen odiar in 12 of the 14 cases. The remaining two have detestar. This reconfirms the impression that hate covers the area of use of two verbs in particular in Portuguese, namely odiar and detestar. The relationship between hate and odiar is dependent on type of object, and can be summed up as follows, when hate is used in the original texts:

Complement clause: ........... no instances of Portuguese odiar Other non-personal object: . ......... approx. 21\% Portuguese odiar Personal object:.................approx. 85\% Portuguese odiar

Translations of English love

Complement clauses

Love is followed by a complement clause in nine out of the 84 occurrences in the COMPARA material, and most commonly so by a to-infinitive clause, exemplified in (14). The only occurrence with an -ing clause is shown in (15).

..., "Mmm, I'd love to see her do Judith Bliss in Hay Fever." ..."hum, adorava vê-la fazer de Judith Bliss no Hay Fever".

[EBDL1T1] She loved working as an obstetrician...

[EBJT2]

Dizia que gostava de trabalhar como obstetra...

As hinted at in the translations of love in both (14) and (15), amar is not used as a translation in any of the nine cases; instead adorar and gostar (de) are used, five and four times, respectively. In other words, the tendency is similar to what was noted for hate-odiar; other Portuguese verbs than the closest counterpart amar take over when love is followed by a complement clause. Although both examples show love in its weakened sense, example (13) deserves special attention. I believe the combination modal + love + to-infinitive clause in particular bears witness to the weakened sense of love when compared to amar (and also Norwegian elske). In fact, Maia (1994/1996, section 7.5.2) draws attention to this in her discussion of the use of modals with verbs of emotion, quoting Quirk et al. $(1985,3.64 \mathrm{n})$ who say that would in such contexts is used "to indicate a tentative desire in polite requests, offers or invitations". Moreover, amar + complement clause is not attested in the original texts of the COMPARA corpus. 
Other non-personal objects

The Portuguese translations of love with other non-personal objects show a similar tendency to that of hate, in that the intuitively closest counterpart amar is far from the most frequent translation. In fact, amar occurs six times, e.g. (16), while adorar is used 11 times, e.g. (17) and gostar (de) eight times, e.g. (18). Estimar is used once, e.g. (19), and in one case some restructuring has taken place in the translation, and an adjective (adorada) can be said to express the content of the verb loved, e.g. (20).

(16) How to love, all kinds, all love.

[ESNG1] Como amar, todas as maneiras, todos amam. ${ }^{10}$

(17) He loved the stories told in pubs at lunchtimes of the editors of old...

[EBIM2]

Adorava as histórias que se contavam nos pubs à hora do almoço sobre os directores de outros tempos...

(18) 'He loves me already, look at him, you can see it!'

- Ele já gosta de mim, olha para ele, não vês?

[EBJT2]

(19) My shame at persecuting a man loved by my master mixes with a perverse desire to continue my assault...

[EURZ1]

A vergonha que sinto de assim atormentar um homem estimado de meu tio mistura-se som o perverso desejo de prosseguir o meu assédio...

(20) And here he was, making himself sick because the pet he loved was stolen.

[EURZ2]

E aqui estava ele, doente porque a sua adorada ave de estimação tinha sido roubada.

The most typical complementation pattern is a non-personal noun phrase, as shown in example (17). Other non-personal nouns or noun phrases include that title/o titulo, fairs/feiras, the noise/o barulho. A passive construction is chosen in one instance, as with estimar in example (19), and an intransitive pattern is found once, as shown in (16) with amar. ${ }^{11}$ Interesting to note with regard to the intran-

[10] The Portuguese translator has interpreted the second instance of love in this sentence as a verb, while I have interpreted it as a noun; it is thus not part of the material studied here.

[11] It is not quite clear how Johansson (1998) classified instances of passive and intransitive constructions. However, he says that "[i]n the few instances of intransitive use, the verbs are translated by their standard counterparts" (ibid., pg. 96). Since the number of instances in Johansson's study is not reduced after mentioning this, I take it to mean that Johansson counted them as instances of the 'non-personal object' category. This is not as straightforward for the passive use, as there is very often an implied personal object involved. However, the four instances of passive and intransitive love do not skew the results unduly. In addition, Maia (1994/1996, section 6.7) notes that "passives with SFoc verbs like love and like are extremely rare". 
sitive pattern is Maia's (1994/1996, section 6.4) observation that amar differs from love in this respect, i.e. intransitive amar is much more frequently attested than intransitive love in her material.

In contrast to the translations of hate, we have seen that the translations of love form a slightly less homogeneous group; instead of two main correspondences as is the case for hate, there are three for love, in addition to a couple of marginal ones. Moreover, the verb is not exclusively followed by a noun phrase. This suggests that love in English may have a wider area of use than amar.

Personal objects

Amar is used as a translation of love followed by a personal object in half of the cases (24 out of 48), and is illustrated in example (21). The other frequent translation correspondence is gostar de, used in 17 cases, and illustrated in example (22). Other, minor, correspondences include three instances of zero correspondence, as in (23), three instances of adorar, e.g. (24), and one instance of estimar, e.g. (25).

(21) "Men of Athens, I honor and love you, but I shall obey God rather than you."

[EUJH1]

- Atenienses, honro-vos e amo-vos, mas devo obedecer a Deus antes de a vós.

(22) 'If you really loved her -'

- Se gostavas mesmo dela...

[EBJT1]

(23) I was raised to be a poet of sorts -- my mother loved Rilke, I was told and to recite epics, to tell stories.

[EURZ2]

Fui educado para ser assim uma espécie de poeta, [Ø] para recitar epopeias. E contar histórias.

(24) Hughie loved her.

O Hughie adorou-a.

(25) Simon loved your uncle.

Simão estimava muito teu tio.

[EBJT1]

[EURZ1]

As was the case in Johansson's material, there are two main translation correspondences of love with a personal object in the English-Portuguese material. Another similarity is that there is no tendency as to what kind of personal relationship is described, that between man-woman, parent-child, friend-friend etc. (i.e. the SENSER and PHENOMENON in Maia's (1994/1996) terms). 
The relationship between hate and odiar was seen to be tied to type of object; this is also the case for the translations of love into amar, where the distribution is as follows:

Complement clause: ........... no instances of Portuguese amar Other non-personal object .......... approx. 19\% Portuguese amar Personal object: ................. approx. 50\% Portuguese amar

While the tendency for odiar and amar as translations of hate and love with non-personal objects (including complement clauses) is virtually the same, amar is proportionally less used as a translation of love with a personal object $(50 \%)$ than odiar as a translation of hate with a personal object (85\%). A more stable relationship between hate and odiar with a personal object is thus noted. This may indicate that love, even with a personal object, is understood as more bleached, i.e. the strength of feeling that is expressed varies from strong to relatively weak. Strong feeling is typically translated as amar, whereas gostar (de) is typically used to express the weakened meaning of love.

\section{[5] CONCLUSIONS}

This study has followed in the footsteps of Johansson's article concerning the relationship between the typical verbs of love and hate in English and Norwegian. The aim was to shed light on the relationship between similar verbs in English and Portuguese. The COMPARA data seem to paint a more complex picture of the use of these verbs across the two languages. In some respects, the Portuguese verbs behave in ways similar to the Norwegian verbs, particularly in that they seem to have a more restricted area of use than their English counterparts.

In other respects, the Portuguese verbs differ from the Norwegian verbs. In original texts, odiar, for example, is shown to combine more easily with nonpersonal objects than Norwegian hate. These and other cross-linguistic observations suggest that the Portuguese verbs may more easily combine the "strong feeling" meaning with non-personal objects than Norwegian, while the English verbs are more often used in a weakened sense. Alternatively, it could point to a middle position for Portuguese, where Norwegian hate expresses the strongest feeling of hate, English hate the weakest, with Portuguese odiar somewhere in between.

The Portuguese translations of love and hate reveal some clear patterns: the English verbs are tied to two or three Portuguese verbs each. Thus the inventory of correspondences is more restricted than the Norwegian correspondences reported by Johansson (1998). The translators seem to be well aware of this division of labour between a small set of Portuguese verbs to cover the meanings of love and hate. Again it is tempting to suggest that Portuguese amar and odiar are in a middle position, in that the two English verbs have the widest area of use 
and the Norwegian verbs the narrowest, with the Portuguese verbs somewhere in between.

As was the case in the English-Norwegian data the Portuguese translation patterns for love and hate are broadly in agreement in terms of complement types. Neither amar nor odiar was found with a complement clause, and only around $20 \%$ of the translations with other non-personal objects had amar or odiar. Personal objects were favoured by both Portuguese verbs. However, in the original data odiar was found to occur with a complement clause, which supports the suggestion that at least one of the Portuguese verbs may have a slightly more weakened sense than its Norwegian counterpart. In this context it should be pointed out that studies of Norwegian elske and hate based on more recent data than the ENPC found evidence of these constructions occurring naturally in (untranslated) Norwegian (Hasselgård 2011; Ebeling 2014). In other words, Norwegian elske and hate were attested with complement clauses. In the original study, Johansson's "immediate reaction was that these were anglicisms" (1998, pg. 93). While I believe that his observation is right, it is also a fact that this construction is on the increase in Norwegian, and what we are witnessing is a language change due to influence from English (Ebeling 2014).

As pointed out by Johansson (1998, pg. 102), “[c]hanges of this kind are natural wherever there are languages in contact, but it is important to be aware of what is going on". Whether similar changes, due to influence from English, are also taking place in Portuguese is hard to determine on the basis of the COMPARA material. To gain insight into the development of the complement patterns of amar and odiar, diachronic Portuguese material (including material of a more recent date) has to be consulted, and will therefore have to await future research.

\section{ACKNOWLEDGEMENTS}

I would like to thank Cristina Mota and Stella Tagnin for their valuable and constructive comments on a previous version of this paper.

\section{APPENDIX}

Overview of the subset of COMPARA used. ${ }^{12}$

\begin{tabular}{lllll}
\hline \multirow{2}{*}{ Corpus ID } & Author & Title & Place of pub./Publisher & \multicolumn{1}{l}{ Year of pub. } \\
& Translator & Title (trans.) & Place of pub./ Publisher (trans.) & Year of pub. (trans.) \\
\hline EBDL1T1 & Lodge, David & Therapy & London: Secker \& Warburg & 1995 \\
& Figueira, Maria do Carmo & Terapia & Lisbon: Gradiva & 1995 \\
EBIM1 & McEwan, Ian & Black Dogs & London: Picador & 1992 \\
& Rodrigues, Fernanda Pinto & Cães Pretos & Lisbon: Gradiva & 1993 \\
EBIM2 & McEwan, Ian & Amsterdam & London: Vintage & 1998 \\
& Bastos, Ana Falcão & Amesterdão & Lisbon: Gradiva & 1999 \\
EBJB1 & Barnes, Julian & Flaubert's Parrot & London: Picador & 1985 \\
& Amador, Ana Maria & O papagaio de Flaubert & Lisbon: Quetzal & 1988 \\
EBJB2 & Barnes, Julian & A History of the World in 10 1/2 Chapters & London: Picador & 1989 \\
& Lima, José Vieira de & A História do Mundo em 10 Capítulos e $1 / 2$. Lisbon: Quetzal & 1990
\end{tabular}

[12] COMPARA v13.1.22, http://www.linguateca.pt/COMPARA/[21-Nov-2014]. 


\begin{tabular}{lllll}
\hline Corpus ID & Author & Title & Place of pub./Publisher & Year of pub. \\
& Translator & Title (trans.) & Place of pub./ Publisher (trans.) & Year of pub. (trans.) \\
\hline EBJT1 & Trollope, Joanna & Next of Kin & London: Black Swan & 1996 \\
& Bastos, Ana Falcão & Parentes próximos & Lisbon: Gradiva & 1998 \\
EBJT2 & Trollope, Joanna & A Spanish Lover & London: Bloomsbury & 1993 \\
& Bastos, Ana Falcão & Um Amante Espanhol & Lisbon: Gradiva & 1999 \\
EBKI1 & Ishiguro, Kazuo & The Unconsoled & London: Faber \& Faber & 1995 \\
& Rodrigues, Fernanda Pinto & Os Inconsolados & Lisbon: Gradiva & 1995 \\
EBKI2 & Ishiguro, Kazuo & The Remains of the Day & London: Faber \& Faber & 1989 \\
& Rodrigues, Fernanda Pinto & Os Despojos do Dia & Lisbon: Gradiva & 1991 \\
ESNG1 & Gordimer, Nadine & My Son's Story & London: Penguin Books & 1990 \\
& Ferraz, Geraldo Galvão & A história do meu filho & São Paulo: Editora Siciliano & 1992 \\
ESNG3 & Gordimer, Nadine & July's People & South Yarmouth: Curley Publishing 1981 \\
& Reis, Paula & A Gente de July & Lisbon: Teorema & 1986 \\
EUJH1 & Heller, Joseph & Picture This & New York: G. P. Putnam's Sons & 1990 \\
& Rodriguez, Cristina & Imaginem que & Lisbon: Difusão Cultural & 1991 \\
EURZ1 & Zimler, Richard & The Last Kabbalist of Lisbon & London: Arcadia Books Ltd. & $1998^{a}$ \\
& Lima, José & O Último Cabalista de Lisboa & Lisbon: Quetzal & 1996 \\
EURZ2 & Zimler, Richard & Angelic Darkness & London: Arcadia Books Ltd. & $2000^{b}$ \\
& Lima, José & Trevas da Luz & Lisbon: Quetzal & 1998 \\
\hline
\end{tabular}

[a] Originally published in 1996.

[b] Originally published in 1998.

TABLE 6: English original texts and their translations into Portuguese in the COMPARA subset (359,281 English words; 350,607 Portuguese words).

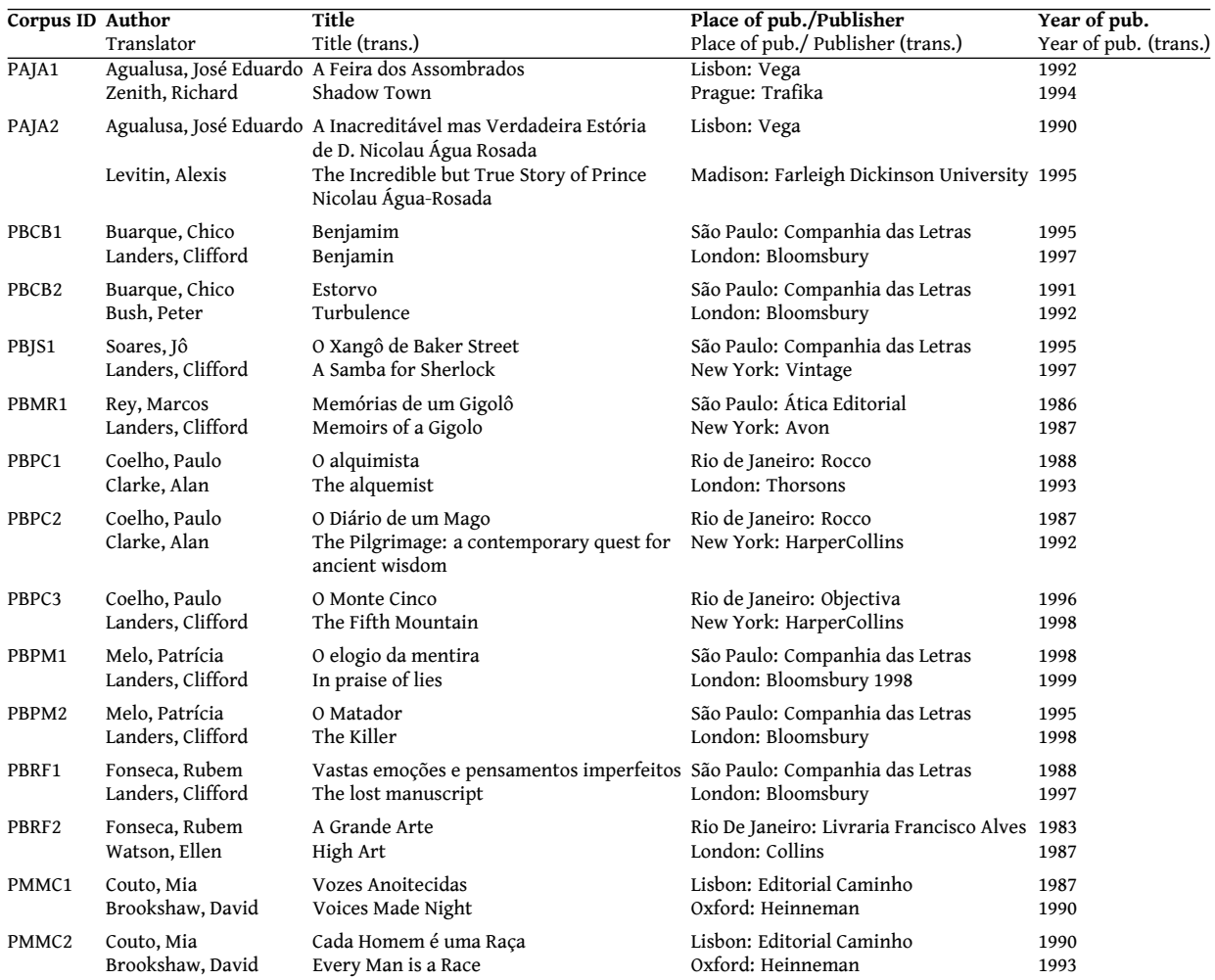




\begin{tabular}{|c|c|c|c|c|}
\hline Corpus ID & $\begin{array}{l}\text { Author } \\
\text { Translator }\end{array}$ & $\begin{array}{l}\text { Title } \\
\text { Title (trans.) }\end{array}$ & $\begin{array}{l}\text { Place of pub./Publisher } \\
\text { Place of pub./ Publisher (trans.) }\end{array}$ & $\begin{array}{l}\text { Year of pub. } \\
\text { Year of pub. (trans.) }\end{array}$ \\
\hline$\overline{\text { PPCP1 }}$ & Cardoso Pires, José & Balada da Praia dos Cães & $\begin{array}{l}\text { Lisbon: Edições “O Jornal”, } \\
\text { Publicações Projornal, Lda. }\end{array}$ & 1983 \\
\hline & Fitton, Mary & Ballad of Dog's Beach & London: John M. Dent & 1986 \\
\hline PPJS1 & $\begin{array}{l}\text { Sena, Jorge de } \\
\text { Byrne, John }\end{array}$ & $\begin{array}{l}\text { Sinais de Fogo } \\
\text { Signs of Fire }\end{array}$ & $\begin{array}{l}\text { Lisbon: Edições 70, Lda. } \\
\text { Manchester: Carcanet Press }\end{array}$ & $\begin{array}{l}1978 \\
1999\end{array}$ \\
\hline PPJSA1 & $\begin{array}{l}\text { Saramago, José } \\
\text { Pontiero, Giovanni }\end{array}$ & $\begin{array}{l}\text { Ensaio Sobre a Cegueira } \\
\text { Blindness }\end{array}$ & $\begin{array}{l}\text { Lisbon: Caminho } \\
\text { London: Harvill Press }\end{array}$ & $\begin{array}{l}1995 \\
1997\end{array}$ \\
\hline PPJSA2 & $\begin{array}{l}\text { Saramago, José } \\
\text { Pontiero, Giovanni }\end{array}$ & $\begin{array}{l}\text { A História do Cerco de Lisboa } \\
\text { The History of the Siege of Lisbon }\end{array}$ & $\begin{array}{l}\text { Lisbon: Caminho } \\
\text { London: Harvill Press }\end{array}$ & $\begin{array}{l}1989 \\
1996\end{array}$ \\
\hline PPLJ1 & $\begin{array}{l}\text { Jorge, Lídia } \\
\text { Costa, Natália and } \\
\text { Ronald W. Sousa }\end{array}$ & $\begin{array}{l}\text { A Costa dos Murmúrios } \\
\text { The Murmuring Coast }\end{array}$ & $\begin{array}{l}\text { Lisbon: Publicações Dom Quixote } \\
\text { Minneapolis: The University of } \\
\text { Minnesota Press }\end{array}$ & $\begin{array}{l}1988 \\
1995\end{array}$ \\
\hline PPMC1 & $\begin{array}{l}\text { Carvalho, Mário de } \\
\text { Rabassa, Gregory }\end{array}$ & $\begin{array}{l}\text { Um deus passeando pela brisa da tarde } \\
\text { A god strolling in the cool of the evening }\end{array}$ & $\begin{array}{l}\text { Lisbon: Caminho } \\
\text { London: Phoenix }\end{array}$ & $\begin{array}{l}1994 \\
1997\end{array}$ \\
\hline
\end{tabular}

TABLE 7: Portuguese original texts and their translations into English in the COMPARA subset (369,203 Portuguese words; 412,704 English words)

\section{REFERENCES}

Altenberg, Bengt. 1999. Adverbial connectors in English and Swedish: Semantic and lexical correspondences. In Hilde Hasselgård \& Signe Oksefjell (eds.), Out of Corpora: Studies in Honour of Stig Johansson, 249-268. Rodopi.

Ebeling, Signe Oksefjell. 2014. Does corpus size matter? Revisiting ENPC case studies with an extended version of the corpus. Paper presented at Languages in Contrast - A symposium in celebration of the 20th anniversary of the Nordic Parallel Corpus project, Lund, 5 December.

Frankenberg-Garcia, Ana \& Diana Santos. 2003. Introducing COMPARA: the Portuguese-English Parallel Corpus. In Federico Zanettin, Silvia Bernardini \& Dominic Stewart (eds.), Corpora in Translator Education, 71-87. St. Jerome.

Gellerstam, Martin. 1986. Translationese in Swedish novels translated from English. In Lars Wollin \& Hans Linquist (eds.), Translation Studies in Scandinavia, 88-95. CWK Gleerup.

Hasselgård, Hilde. 2011. Loving and hating in English and Norwegian speech. Paper presented at the Jan Svartvik Birthday Symposium, Lund, 19 August.

Johansson, Stig. 1998. Loving and hating in English and Norwegian: A corpusbased contrastive study. In Dorte Albrechtsen, Birgit Henriksen, Inger M. Meesand \& Erik Poulsen (eds.), Perspectives on Foreign and Second Language Pedagogy, 93-103. Odense University Press.

Johansson, Stig. 2007. Seeing through Multilingual Corpora: On the Use of Corpora in Contrastive Studies, vol. 26 Studies in corpus linguistics. John Benjamins.

Johansson, Stig \& Knut Hofland. 1994. Towards an English-Norwegian Parallel Corpus. In Peter Schneider Udo Fries, Gunnel Tottie (ed.), Creating and Using 
English Language Corpora: Papers from the Fourteenth International Conference on English Language Research on Computerized Corpora, 1993, 25-37. Rodopi.

Maia, Belinda. 1994/1996. A Contribution to the Study of the Language of Emotion in English and Portuguese: FLUP PhD dissertation. Versão revista: 1996.

Maia, Belinda \& Diana Santos. 2012. Who is afraid of ... what? - In English and in Portuguese. In Signe Oksefjell Ebeling, Jarle Ebeling \& Hilde Hasselgård (eds.), Aspects of corpus linguistics: compilation, annotation, analysis $12, \mathrm{~s} / \mathrm{pp}$.

Oksefjell, Signe. 1999. A description of the English-Norwegian Parallel Corpus: Compilation and further developments. International Journal of Corpus Linguistics 4(2). 197-219.

Quirk, Randolph, Geoffrey Leech Sidney Greenbaum \& Jan Svartvik. 1985. A Comprehensive Grammar of the English Language. Longman.

Taboada, Maite, Marta Carretero \& Jennifer Hinnell. 2014. Loving and hating the movies in English, German and Spanish. Languages in Contrast 14(1). 127-161.

Signe Oksefjell Ebeling

University of Oslo

s.o.ebeling@ilos.uio.no 